\title{
The Use of Counseling Cognitive Behavior Therapy (CBT) Approach to Change Students' Attitudes toward Cheating Behavior at SMK 1 Gunung Talang
}

\author{
Emdorizal $^{1}$, Yeni Karnelii ${ }^{1}$, Marlina ${ }^{1}$ \\ ${ }^{1}$ Universitas Negeri Padang \\ Corresponding Author: chanktanjung@gmail.com
}

\begin{abstract}
Students sometimes make cheating behaviors to achieve good grades in the exam. Cheating behavior is clearly cheating behavior that students should not do. The purpose of this study is to change the cheating behavior of students using the CBT approach, setting group. This study is a Quasi Experiment that uses quantitative methods and The Non-Equivalent Control Group Desig. The research subjects of class X of SMK Negeri 1 Gunung Talang was identified as having a tendency to cheat. The research instrument used a cheating behavior scale that fulfilled the requirements of the research instrument, then analyzed using the Wilcoxon SignedRank Test and the Kolmogorov Smirnov 2 Independent Samples test. The findings of this study show that in general CBT counseling group settings are effective for changing student attitudes toward cheating behavior. This finding can be discussed further.
\end{abstract}

Keywords: Cheating Behavior, Counseling, CBT group setting

\section{Introduction}

One of the problems that are of concern in education in Indonesia and even internationally is cheating. Cheating is something that is familiar to students and students (Amigud \& Lancaster, 2019; Shafaei, Nejati, Quazi, \& Vonder Heidt, 2016). Cheating problems are always related to tests or tests. Cheating behavior in schools is considered as an antecedent of future unethical behavior (Elias, 2009; Farnese, Tramontano, Fida, \& Paciello, 2011). Cheating is a phenomenon always appears to accompany the learning process activities, but ironically it rarely gets serious attention from education practitioners in Indonesia (Kurniasih, Limbong, \& Handayani, 2019; Amigud \& Lancaster, 2019; Elias, 2009; Farnese et al., 2011; Kurniasih et al., 2019; McCabe, Klebe, \& Butterfield, 2001) Some experts say cheating behavior is influenced by several factors such as the desire to get high grades, educational environment, difficulties faced, lack of quality educators, pressure to get grades, desire to avoid failure, perception that schools do things that are unfair (Amigud \& Lancaster, 2019b; Elias, 2009; Fitri, Dahliana, \& Nurdin, 2017; Helmi, 2017). Based on these opinions, it can be concluded that cheating is a violation of rules in education because it uses dishonest ways to achieve lofty academic values. 
In Indonesia, alone cheating behavior has received serious attention seen from a survey conducted by several institutions. Based on the results of the R \& D Media Group survey conducted in six major cities in Indonesia (Makassar, Surabaya, Yogyakarta, Bandung, Jakarta and Medan) it was revealed that nearly $70 \%$ of students answered they had cheated while they were in school and college (Purwono, 2014; Schwieren \& Weichselbaumer, 2010; Widianto \& Sari, 2017). Cheating behavior is a problem that is considered as an interaction between various systems within individuals and their environment. The most recognized types of cheating are mass via SMS (short message), chat group, paper, or body language code (Agustin, 2013; Kusumastuti, 2015; Purwono, 2014; Widianto \& Sari, 2017). Until the buying and selling, mode leaked questions and the role of the success team (teacher, school, supervisor) or other parties (tutoring and jockeys).

Cheating behavior is one serious problem that must be dealt with immediately, especially in the field of education. Wrong personnel that can help change the cheating behavior of students are BK teachers or counselors (Agustin, 2013; Helmi, 2017; Kusumastuti, 2015; Purwono, 2014). The effort that can be done by counseling teachers is to carry out various types of services such as individual counseling, group counseling, and other services in guidance and counseling. Researchers tried to provide services in counseling guidance that was more effective to improve students' understanding of cheating behavior by using CBT counseling group settings. The results of the research conducted by Agustin (2013) reveal that the forms of cheating behavior that are often carried by students are planned with a high category, while the forms of social-passive and individual-oppurtunistic cheating behavior are in the base and very low categories. In line with that, the results of the study (Hartanto, 2012) regarding the use of CBT to reduce cheating behavior in middle school students showed that cheating behavior at the secondary school level was mostly carried out in the form of social-active, namely cheating behavior where students copy, see or ask answers from people.

Counseling using CBT setting groups can identify four systems, namely cognition, emotions or effects, physiological behavior. These systems interact with each other reciprocally and also interact with the environment in social situations. CBT plays a role in restructuring negative perceptive, non-adaptive and uneasy physical behavior. CBT is one approach in counseling designed to solve client problems at this time by conducting cognitive restructuring, deviant beliefs and behaviors (Fadil, Sunawan, \& Awalya, 2019; Yuliyanawati, Wibowo, \& Japar, 2018).

The researcher wanted to see the effectiveness of CBT counseling group settings to change students' attitudes towards cheating behavior. The CBT approach emphasizes the important role of thinking about how individuals perceive and what individuals do (Boelen, de Keijser, van den Hout, \& van den Bout, 2007; Farnese et al., 2011). The basic concept of this approach is to change negative thoughts and behaviors that greatly affect emotions by drawing attention to mindset and mood (Cahyadi, 2018; Sulistiya, Sugiharto, \& Mulawarman, 2017). The study will look at how effective the use of cognitive-behavioral therapy (CBT) counseling approach is to change students' attitudes toward cheating behavior.

\section{Method}

This research is a quantitative study with a quasi-experimental research design of The Non Equivalent Control Group. Before carrying out the CBT counseling activity the group was first given a pretest, the experimental group was given CBT 
counseling treatment group, while the control group was given counseling services without using the CBT approach. Both groups were given with the same instrument, to see which groups were better at getting results. The results of the pretest and posttest of the experimental group and the control group were compared while simultaneously testing the hypothesis that had been proposed.

The subjects in this study were 20 students at SMK Negeri 1 Gunung Talang obtained through purposive sampling. The researcher chose Mount Talang N 1 as the subject because after the researchers tested the instruments in two schools on Mount Talang, namely SMA N 1 and SMK N 1 Gunung Talang that cheating behavior was mostly carried out by Vocational students compared to high school. The instrument that the researcher gave was an instrument of cheating behavior. This study uses a closed questionnaire Likert scale treatment model that the researchers did was five times. In order to get the right and accurate analysis results and avoid the risk of manual calculation errors, in testing the hypothesis using the SPSS program assistance.

\section{Results and Discussion}

Research data obtained based on the results of giving the instrument before being given treatment (pretest) and after being given treatment (posttest). Next is the translation of the pretest and posttest scores in the experimental group.

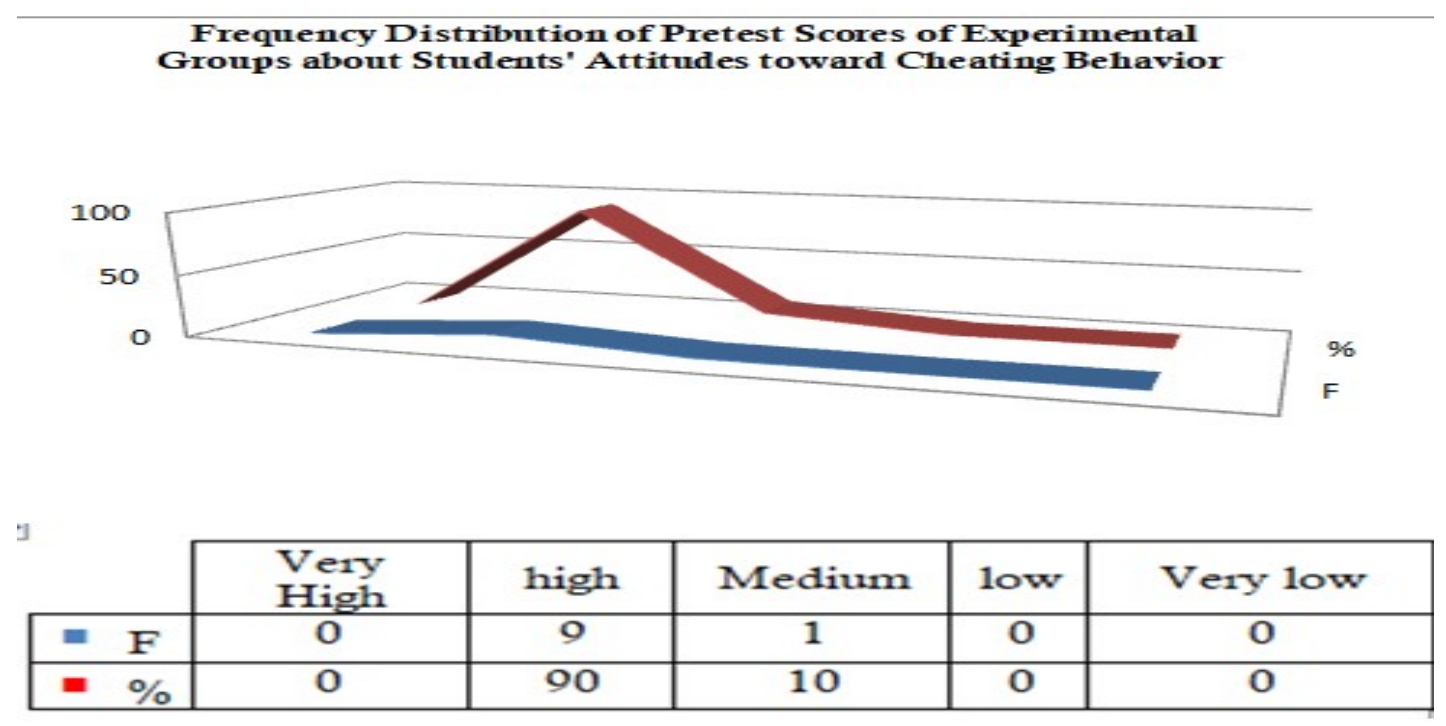

Figure 1. Distribution Graph of Pretest Scores of Experimental Groups about Students on Cheating Behavior

Further Frequency Distribution of Posttest Scores of Experimental Groups about Student Attitudes toward Cheating Behavior can be seen in Figure 2 below. 


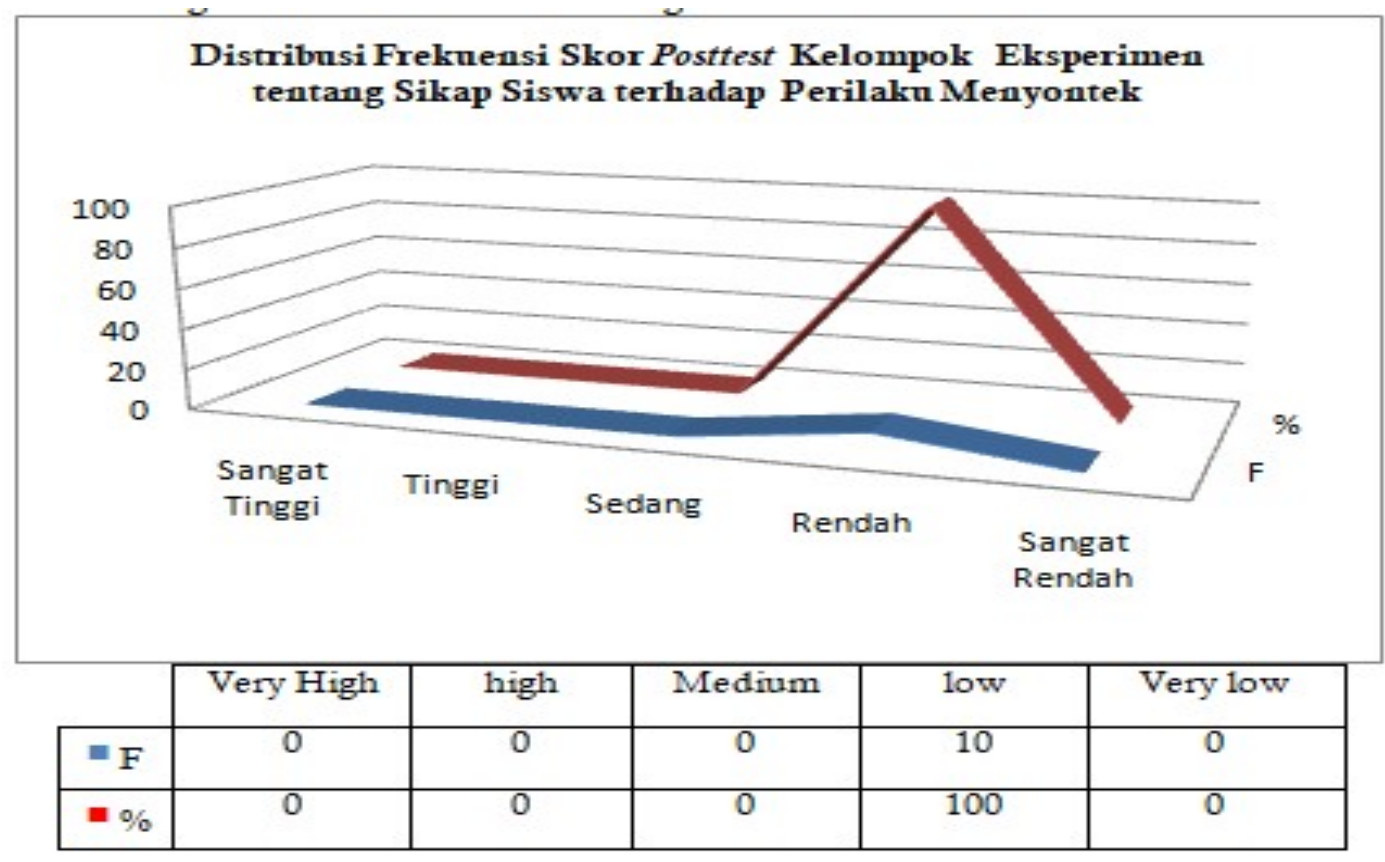

Figure 2. Graph of Frequency Distribution of Posttest Scores of Experimental Groups about Students' Attitudes toward Cheating Behavior

Based on the previous two graphic images, it can be seen that there is a decrease in student attitudes toward cheating behavior of students after being given CBT counseling in group settings. Overall, the decline occurred in the number of score gains and categorically students towards cheating behavior. Previously, 9 people were in the high category, and one person was in the medium category. After being given the CBT setting group, all student group members had attitudes towards cheating behavior in the low category. This means that there are no more group members who have a high attitude towards cheating. Group members already understand and know that cheating behavior can be self-defeating and can damage other people's trust in themselves.

CBT Counseling Group setting is a series of activities that provide experiences to students in interacting with each other in a group setting, solving a common problem, exchanging ideas, thus changing perceptions, views and attitudes towards the problem / topic being discussed (Winkel, 2004). Through CBT counseling the group setting students to get a new understanding, so they can change their attitudes and views on cheating behavior. After students were given CBT group setting counseling, the posttest score decreased in scores. Acquiring the attitude score of the experimental group decreased to the low category. The difference in the mean score of students' attitudes toward cheating behavior before and after being given treatment is quite high. The difference in attitude's scores attitudes toward cheating behavior is the result of being given CBT counseling group settings. 


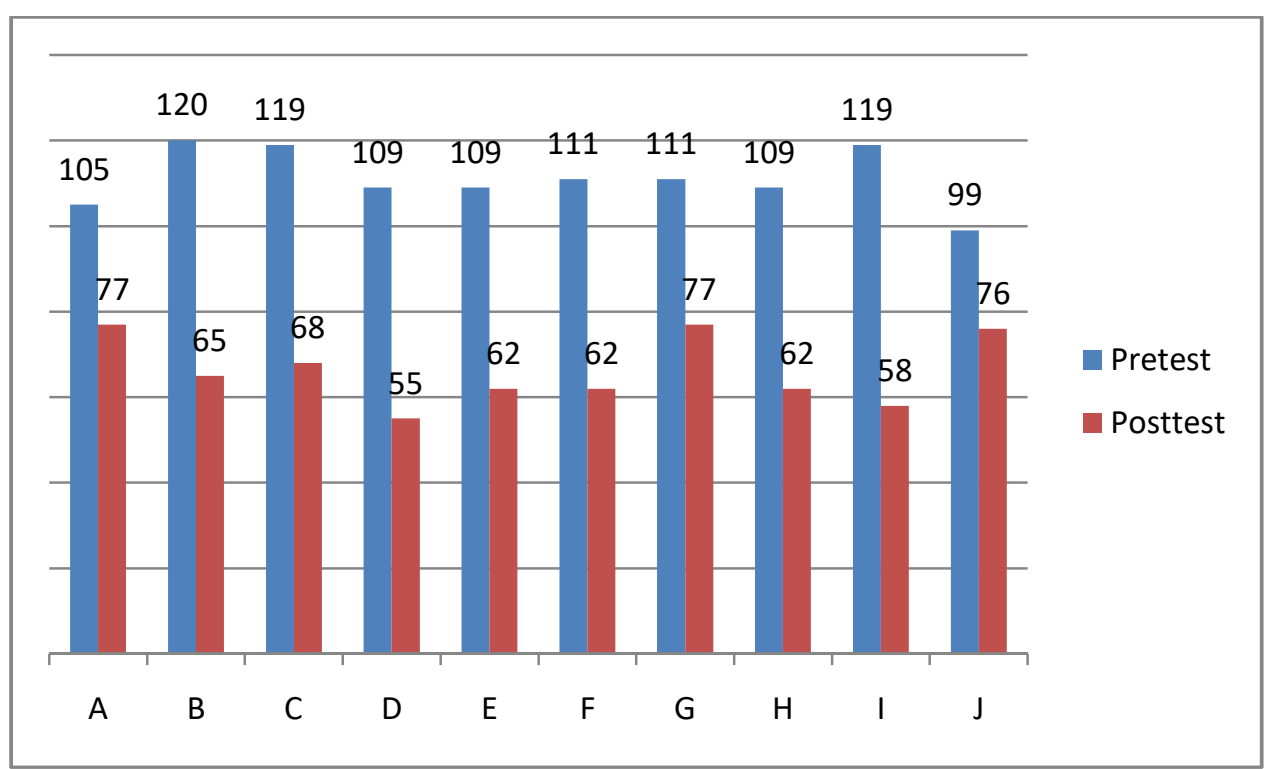

Figure 3. Results of the pretest and posttest of the experimental group

Figure 3. CBT counseling is seen group setting is one of the more effective strategies in counseling in an effort to change students' attitudes towards cheating behavior. Through CBT group setting counseling, group members are able to change negative thinking to be positive (Dermatis \& Egelko, 2014; Sulistiya et al., 2017). CBT counseling group setting is a psychotherapeutic approach used by counselors to help individuals in a direction. A variety of techniques for changing cognition, emotions and behavior are the most important parts of CBT. This method develops according to the needs of the counselee, where the counselor is active, directive, limited in time, structured, and centered on the counselee. Cognitive aspects in CBT include changing ways of thinking, beliefs, attitudes, assumptions, imagination and facilitating counselees to learn to recognize and change errors in aspects (Jennings, J. L., \& Deming, 2013).

CBT emphasizes that problematic behavior is caused by irrational thinking, so the focus of handling the CBT approach is irrational thinking. The results showed that rational and irrational beliefs can determine unhealthy anger and functional and dysfunctional anger. One irrational thought in CBT is that it is bad and annoying if everything happens is not as expected, and is loved and approved by others is something very important and running away from difficulties, and responsibilities is easier than facing it. When unpleasant things happen, someone tends to create irrational beliefs about the event. Effective CBT counseling group settings capable of providing negative behavioral changes may include quitting. In group activities letting others talk, staying quiet and listening, using less detail, lowering the volume and speaking less quickly will be able to reduce beliefs (Jennings, J. L., \& Deming, 2013).

Based on the explanation above, if it is linked, students who tend are from false beliefs about cheat wrong attitudes will bring students to do things by making every effort so that the test scores are high. Students who have a positive (supportive) attitude to cheating behavior will have deviant learning habits, namely by deceiving during the exam. This belief is what gives birth to irrational thoughts in students about how to get the value of the lesson to be good even though it is taken in the wrong way. Furthermore, based on the process of implementing the activities revealed various causes of students having attitudes towards high cheating behavior. The irrational thinking group members have about cheating 
between them, the assumption that cheating behavior carried out by someone or a student is normal. The important thing is that the test results get the best value.

The success of this activity is also not immune from the success of all subjects in identifying negative self-statements correctly and replacing them with more positive selfstatements. Based on the results of work one assignment, all subjects have been able to understand that feelings and behaviors are not directly caused by the events they experience, but rather because of their thoughts. After understanding the connection between thoughts and feelings, the subject identifies whether the mind is rational (in therapy called fact) or irrational (in therapy called opinion), by opposing the mind with challenging questions. Group guidance activities using the CBT approach regarding changes in student attitudes towards cheating behavior (Changes in Core Beliefs) or developing an effective philosophy of life (Proudfoot, J., Ryden, C ., Everitt, B., Shapiro, DA, Goldberg, D., Mann, A., \& Gray, 2004).

Furthermore, to see more clearly the differences in student attitudes towards cheating behavior in the control group before and after counseling without the CBT setting group, the previous data analysis was performed using Wilcoxon Signed Ranks Test statistical analysis techniques through the SPSS computer program. Based on the results of data analysis, the Asymp value is obtained. Sig. (2-tailed) Value 0.008 smaller than 0.05 , it can be concluded that "H0 is rejected and H1 is accepted." This means that there is a difference between students' attitudes to cheating behavior for the pretest and posttest of the control group after taking counseling without CBT group settings. Thus, the second hypothesis tested in this study is rejected, which states that there is no difference in student attitudes toward cheating control groups before and after given CBT counseling treatment setting group CBT. However, the results of the analysis stated that there were differences in student attitudes toward cheating behavior in the control group before and after being given CBT.

CBT group settings allow students to acquire the abilities needed in relationships with others and themselves. This can happen by growing intensive group dynamics and discussing hot topics, will encourage and help students develop feelings, thoughts, perceptions, insights, and attitudes that support the realization of more effective and responsible behavior.

CBT counseling group settings are carried out according to the stages, namely five stages of activities, starting from the stage of formation, transition, activity, conclusion, and termination. Procedure, the implementation of CBT counseling group settings is the same as counseling without the CBT setting group, only at the activity stage. Discussion of topics in the control group did not use special techniques such as CBT counseling group settings. At the activity stage the task topic is discussed together with group members and group leaders as facilitators in the activity. However, in its implementation, group members are not yet fully active in the group. Students only get information through group leaders. Disclosure of student attitudes towards cheating behavior is less apparent. Some students are reluctant to argue, choose to be quiet and just listen.

Based on the observations of researchers meeting group dynamics has not been prominent. The researcher interviewed several members of the control group interrupted by CBT counseling activities group setting for the activity of students talking in groups. Responding to the results of the implementation of activities at the first meeting, researchers conducted various evaluations about the implementation of activities, starting from the techniques used, group dynamics and group member constraints. Membership is one of the main elements in the group's life process. The role of the group will not materialize without 
active participation by group members, and even more than that. Prayitno (2012) states that the role of group members in CBT counseling group settings is from, by and for the members themselves.

So, be concluded that students' attitudes to cheating behavior can be changed by using CBT counseling group settings without using CBT counseling. However, the changes are not effective from counseling without the CBT setting group, because in the group guidance activities, the members only get new information and understanding from group leaders and opinions from some group members who argue without direct and independent activities in the group. Differences in student attitudes toward cheating behavior in the experimental group and controls can be seen in the figure below.

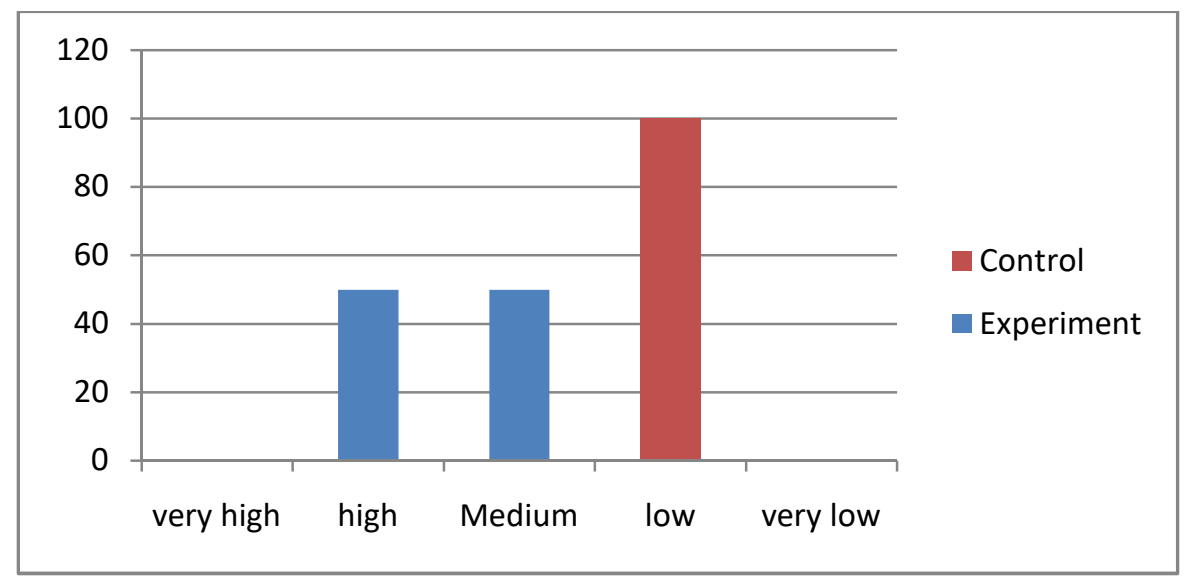

\section{Figure 4. Graph of Differences in Posttest Scores between Experimental Groups and Control Groups.}

Based on figure 4 above, it can be seen the difference in the percentage of the average score of student attitudes toward cheating behavior between the experimental group and the control group. To see more clearly the differences in student attitudes toward cheating behavior, the above data were then analyzed using Kolmogorov Smirnov 2 independent statistical techniques through the SPSS computer program. Based on the results of the analysis of the data obtained the value of Asymp. Sig. (2-tailed) For the two-sided, test is 0,000 in another form $(0,000<0,05)$. Then $\mathrm{H} 0$ is rejected and $\mathrm{H} 1$ is accepted means, there is a significant difference in student attitudes toward cheating behavior in the experimental group who followed the CBT counseling setting for the control group who followed counseling without the CBT group setting.

Based on the posttest results in the experimental group treated with programmed group guidance, changes were obtained. Result student attitude's scores on cheating behavior which were originally in the high category, decreased to a low category. Whereas in the control group that was not given treatment, the group guidance was programmed, also a decrease. The results of attitude scores on cheating behavior were initially in the high category, in the control group, there were still five students who had attitudes toward high cheating behavior and one student did not experience a decrease in attitude scores towards cheating behavior.

CBT is more effectively presented in groups than individuals because in groups, each member will realize that they are not only themselves in dealing with the problem, so that they can provide mutual support and become a source of excellent inspiration for other members. 
As we know, teenagers and students always have irrational beliefs when something bad happens in their lives. This therapy also quickly teaches counselees how to overcome practical problems of life (Cuijpers, P., Berking, M., Andersson, G., Quigley, L., Kleiboer, A., \& Dobson, 2013). Clients are taught to understand themselves, understand others, react differently, and to change their basic personality patterns and philosophies by correcting wrong thinking. This is in accordance with the principle of implementing CBT based on the evolving formulation of client problems and client cognitive conceptualization (Jennings, J. L., \& Deming, 2013). The formulation of counseling continues to be improved along with the development of evaluations from each counseling session. At a strategic time, the counselor coordinates the findings of the client's cognitive conceptualization that deviates and rectifies it so that it can help clients adjust between thinking, feeling and acting.

Cheating behavior is a problem that is considered as an interaction between various systems within individuals and their environment. CBT identifies four systems, namely cognition, emotion or effect, physiological behavior. These systems interact with each other reciprocally and also interact with the environment in social situations. CBT plays a role in restructuring negative cognitive, non-adaptive and physically unsettled behaviors. The CBT approach also encourages individuals to open asks with interest how the daily lives of individuals. Individuals learn to try to control themselves over thought patterns and feelings so that get a better life.

\section{Conclusion}

Based on the research data, it can be concluded that in general CBT counseling group settings effectively change students' attitudes towards cheating behavior. Specifically from this study, it can be seen (1) there are differences in the score of student attitudes toward cheating behavior in the group before and after participating in group counseling using the CBT approach, where the score after treatment was significantly lower than before treatment, (2) there are differences in the score of student attitudes toward cheating behavior of the control group before and after participating in group guidance without using the CBT approach, where the score after treatment has decreased, (3) there is a difference in average scores on attitude's students on cheating behavior in the experimental group who took group guidance the CBT approach and the control group that followed group guidance without using the CBT approach with the mean score group meaningfully subordinate than the control group.

So it can be concluded that attitudes towards student attitudes toward cheating behavior can be changed by CBT counseling activities in group setting and counseling without the CBT group setting. However, in terms of scores and process activities, the experimental group was more effective in reducing students' cheating attitude. In group guidance activities, using CBT counseling group settings focuses more on changes in students' irrational thinking about cheating using cognitive and behavioral techniques, so students can respond to it selectively and reduce the tendency of students to cheat at school.

\section{Reference}

Agustin, V. (2013). Perilaku Menyontek Siswa SMA Negeri di Kota Padang serta Upaya Pencegahan Oleh Guru BK. Konselor, 2(1).

Amigud, A., \& Lancaster, T. (2019a). 246 reasons to cheat: An analysis of students' reasons for seeking to outsource academic work. Computers and Education, 134, 98-107. 
https://doi.org/10.1016/j.compedu.2019.01.017

Amigud, A., \& Lancaster, T. (2019b). 246 reasons to cheat: An analysis of students' reasons for seeking to outsource academic work. Computers \& Education, 134, 98-107.

Boelen, P. A., de Keijser, J., van den Hout, M. A., \& van den Bout, J. (2007). Treatment of complicated grief: a comparison between cognitive-behavioral therapy and supportive counseling. Journal of Consulting and Clinical Psychology, 75(2), 277.

Cahyadi, R. (2018). Keefektifan Bimbingan Kelompok Cognitive Behavior dalam Mereduksi Pola Pikir Negatif Siswa SMK. Perspektif Ilmu Pendidikan, 32(2), 143-152.

Cuijpers, P., Berking, M., Andersson, G., Quigley, L., Kleiboer, A., \& Dobson, K. (2013). A Meta-Analysis of Cognitive-Behavioural Therapy for Adult Depression, Alone and in Comparison with Other Treatments. The Canadian Journal of Psychiatry, 58(7, 376-385.

Dermatis, H., \& Egelko, S. (2014). Buddhist mindfulness as an influence in recent empirical CBT approaches to addiction: Convergence with the alcoholics anonymous model. Alcoholism Treatment Quarterly, 32(2-3), 194-213. https://doi.org/10.1080/07347324.2014.907012

Elias, R. Z. (2009). The impact of anti-intellectualism attitudes and academic self-efficacy on business students' perceptions of cheating. Journal of Business Ethics, 86(2), 199-209.

Fadil, M., Sunawan, S., \& Awalya, A. (2019). The Effectiveness of Group Counselling with Cognitive Restructuring and Self-Management Techniques to Reduce Internet Addiction. Jurnal Bimbingan Konseling, 134-139.

Farnese, M. L., Tramontano, C., Fida, R., \& Paciello, M. (2011). Cheating behaviors in academic context: Does academic moral disengagement matter? Procedia - Social and Behavioral Sciences, 29, 356-365. https://doi.org/10.1016/j.sbspro.2011.11.250

Fitri, M., Dahliana, D., \& Nurdin, S. (2017). Faktor-Faktor yang Mempengaruhi Perilaku Menyontek Pada Siswa SMA Negeri dalam Wilayah Kota Takengon. JIMBK: Jurnal Ilmiah Mahasiswa Bimbingan \& Konseling, 2(1).

Hartanto, D. (2012). Bimbingan \& konseling menyontek: Mengungkap akar masalah dan solusinya. Jakarta: Indeks.

Helmi, G. (2017). Upaya guru mata pelajaran dan guru BK dalam mencegah perilaku menyontek (Studi Pada SMA Negeri Se-Kota Padangsidimpuan). WAHANA DIDAKTIKA, 15(3).

Jennings, J. L., \& Deming, A. (2013). Effectively Utilizing the Behavioral In CognitiveBehavioral Group Therapy of Sex Offenders. International Journal of Behavioral Consultation and Therapy, 8(2), 7-13.

Kurniasih, P., Limbong, E. G., \& Handayani, D. (2019). Infografis Alasan Menyontek dan Tipe-Tipe Penyontek: Pandangan Etika Mengenai Perilaku Menyontek. Jurnal Desain, 6(02), 112-128.

Kusumastuti, L. (2015). Kejujuran Akademik Pada Siswa Sekolah Menengah Pertama. Universitas Muhammadiyah Surakarta.

McCabe, D. L., Klebe, L. T., \& Butterfield, K. D. (2001). Cheating in Academic Institutions: A Decade of Research. Ethics $\mathcal{E}$ Behavior, 11(3), 219-232. 
https://doi.org/10.1207/S15327019EB1103

Prayitno. (2012). Jenis Layanan dan Kegiatan Pendukung Konseling. Padang: FIP UNP.

Proudfoot, J., Ryden, C., Everitt, B., Shapiro, D. A., Goldberg, D., Mann, A., ... \& Gray, J. A. (2004). Clinical Efficacy of Computerised Cognitive-Behavioural Therapy for Anxiety and Depression In Primary Care: Randomised Controlled Trial. The British Journal Of Psychiatry, 185(1), 46-54.

Purwono, H. (2014). Pengaruh Handphone dan Tingkat Kedisiplinan Belajar Terhadap Perilaku Menyontek. Educatio Vitae, 1(1).

Schwieren, C., \& Weichselbaumer, D. (2010). Does competition enhance performance or cheating? A laboratory experiment. Journal of Economic Psychology, 31(3), 241-253.

Shafaei, A., Nejati, M., Quazi, A., \& Von der Heidt, T. (2016). 'When in Rome, do as the Romans do'Do international students' acculturation attitudes impact their ethical academic conduct? Higher Education, 71(5), 651-666.

Sulistiya, E., Sugiharto, D. Y. P., \& Mulawarman, M. (2017). Dampak Konseling Kelompok Cognitive Behavior Therapy (CBT) Teknik Cognitive Restructuring untuk Meningkatkan Body Image. Jurnal Bimbingan Konseling, 6(2), 135-140.

Widianto, A., \& Sari, Y. P. (2017). Deteksi Kecurangan Akademik Pada Mahasiswa D Iii Akuntansi Politeknik Harapan Bersama Tegal Dengan Modelfraud Triangle. Jurnal Aksi (Akuntansi Dan Sistem Informasi), 2(1), 29-37.

Winkel. (2004). Bimbingan dan Konseling di Institusi Pendidikan. Jakarta: Grasindo.

Yuliyanawati, I., Wibowo, M. E., \& Japar, M. (2018). The Effectiveness of Cognitive Behavior Therapy Group Conseling Cognitive with Cognitive Restructuring and Thought Stopping Techniques to Reduce Students Consumptive Behavior. Jurnal Bimbingan Konseling, 7(2), 125-131. 